\title{
Türkiye'deki Kamu Hastanelerinde İdari Pozisyonda Görev Yapan Hekimlerin Profillerine Yönelik Bir Çalışma
}

\section{A Study on The Proile of Physicians Who Work in Administrative Positions in the Public Hospitals in Turkey}

\author{
Ramazan Rüçhan Kaya ${ }^{1 *}$, Ahmet Alkan² \\ ${ }^{1}$ Uşak Üniversitesi Sağlık Hizmetleri Meslek Yüksekokulu, Uşak, Türkiye \\ ${ }^{2}$ Süleyman Demirel Üniversitesi, Isparta, Türkiye \\ e-mail: ruchan1903@gmail.com, ahmetalkan@sdu.edu.tr. \\ ORCID: 0000-0001-6520-1848 \\ ORCID: 0000-0002-4964-8591 \\ *Sorumlu yazar/ Corresponding Author: Ramazan Rüçhan Kaya \\ Gönderim Tarihi / Received: 23.09.2020 \\ Kabul Tarihi / Accepted: 13.01.2021 \\ DOI: $10.34087 /$ cbusbed. 799117 \\ $\ddot{\mathbf{O z}}$
}

Giriş ve Amaç: Hekimler sağlık hizmetlerinin sunumunda uygulayıcı konumunda oldukları için onlar olmadan sağlık hizmetlerini düşünmek imkânsızdır. Türkiye'de hekim adayları (hazırlık hariç) altı yıllık bir eğitimle yetiştirilmektedir. Hem devlet hem de hekim adayı bu süreçte maddi manevi bir yükün altına girmektedir. Hekimlerin sağlık alanında ekip lideri konumunda olmaları onların sağlık kurumlarındaki idari görevlerde de istihdam edilmelerini beraberinde getirmektedir. Ancak idari görevler hekimlerin, hekimlik ve yöneticilik arasında kalmasına ve körelmesine sebep olabilecektir. Bu çalışmayla Türkiye’de idari pozisyonlarda görev yapan hekimlerin profillerinin tespit edilmesi hedeflenmektedir.

Gereç ve Yöntemler: $\mathrm{Bu}$ çalışma ikincil verilerden yararlanılan nicel bir araştırmadır. Çalışmanın evreni Türkiye'deki kamu hastanelerinden oluşmaktadır. Örneklem seçilmeden, evrenin tamamına ulaşılmaya çalışılmıştır. Elde edilen veriler SPSS programına aktarılarak frekans dağılımlarına bakılmıştır.

Bulgular: Çalışma kapsamında 1638 hekim yöneticinin profilleri incelenmiştir. Bu kişilerden 577'si başhekim geriye kalanlar ise başhekim yardımcılarından oluşmaktadır. Başhekim ve başhekim yardımcılarının yaklaşık olarak beşte biri (\%18.1) kadınlardan oluşmaktadır. Başhekimlerden \%11.1'i kadınlardan oluşurken \%88.9'u erkeklerden oluşmaktadır. Çalışmada hekim yöneticilerin büyük çoğunluğunun (\%63.2) uzman hekimler olduğu sonucuna ulaşılmıştır.

Sonuç: Hekim açığı fazla olan Türkiye'de bir de başhekim ve başhekim yardımcılığ gibi idari pozisyonlara uzman hekimlerin getirilmesinin bu açığı daha da yükselteceği düşünülmektedir. Bu çalışmayla maddi/manevi oldukça yüksek maliyetlerle yetişen uzman hekimlerin mesleklerine yabancılaşacakları idari pozisyonlara getirilmesi yerine, en tepede denetleyicilerin yine hekim olması kaydıyla, başhekim yardımcısı gibi daha alt pozisyonlara alana yatkın meslek gruplarından (sağlık yönetimi, işletme, hemşirelik vb. mezunu) kişilerin getirilmesi önerilmektedir.

Anahtar kelimeler: Hastane Yönetimi, Hekimler, Hekim Yöneticiler, İdari Görev, Yönetim

\footnotetext{
Abstract

Objective: It is impossible to think about health services without physicians because they are practitioners in the provision of medical health services. Physician candidates in Turkey (excluding preparation) are grown to a six-year education. Both the state and the candidate of physician are under a material and moral burden in this process. Today, the positions of the team leaders in the field of healthcare physicians can cause them to be included in administrative positions in health institutions. However, it may cause the physicians who are in administrative positions to remain between physician and management and become blind. In this study, the physicians who work in administrative positions in Turkey, aims to identify the profile.

Material and Methods: This study is a quantitative study using secondary data. The universe of the study consists of public hospitals in Turkey. Without choosing the sample, it was tried to reach the whole universe. The frequency distributions were analyzed by transferring the obtained data to the SPSS program.
} 
Results: Within the scope of the study, profiles of 1638 physician managers were examined. 577 of these persons are chief physicians and the rest are deputy chief physicians. Approximately one-fifth $(18.1 \%)$ of the chief physician and deputy chiefs are women. While $11.1 \%$ of the chief physicians are women, $88.9 \%$ are men. In the study, it was concluded that the majority of physician managers $(63.2 \%)$ were specialist physicians.

Conclusion: : It can be considered that bringing specialist physicians to administrative positions such as chief physician and assistant chief physician in Turkey with a high physician deficit will increase this deficit. Rather than bringing specialist physicians who grow up with this material / moral cost and time loss to administrative positions where they will be alienated from their professions, people from occupational groups (health management, bachelor degree etc.) lower positions (such as deputy chief physician) provided that supervisors are physicians at the top, is recommended.

Keywords: Administrative Function, Hospital Management, Management, Physicians, Physician Manager.

\begin{abstract}
1. Giriş
Hekimlik sağlık hizmetlerinin sunumunda yer alan birimler içerisinde merkezi bir konumda yer almaktadır. Bir hastalı̆̆ın teşhisi, tedavisi, rehabilitasyonu gibi tüm aşamalarda hekimlerin ekip lideri konumunda olduğu yadsınamaz bir gerçektir. Sağlık hizmetlerindeki bu ekip liderliği durumu hekimleri makro ölçekte sağlık yönetimi, daha alt boyutta ise hastane yönetimlerinde idareci pozisyonlarına namzet hale getirmektedir. Günümüzde birçok ülkede hekimler hastanelerin yönetim kademelerinde ve hatta hükümetler içerisinde sağlık bakanlı̆̆ı gibi üst pozisyonlarda bulunmaktadır.
\end{abstract}

Türkiye Cumhuriyeti Sağlık Bakanlı̆̆ı'nın son yayınladığı istatistiklere göre Türkiye'de 97.145'u Sağlık Bakanlığı bünyesinde olmak üzere toplam 160.810 hekim bulunmaktadır. Ayrıca hekime müracaat sayısının 812 milyon 903 bin 622 olduğu ve kişi başına hekime müracaat sayısının 9.8 olduğu düşünüldüğünde [1], yaklaşık 83 milyon nüfusa [2] sahip olan Türkiye'de hekim sayısının ne denli önemli olduğu açıktır. OECD verilerine göre Türkiye'de her 1000 kişiye yaklaşık 1.9 hekim düşmektedir. Bu oranla Türkiye OECD tarafından incelenen 37 ülke arasında son sırada yer almaktadır [3]. Dolayısıyla Türkiye'nin hekim sayısı açısından fakir bir ülke olması her bir hekimin değerini daha da artırmaktadır.

Geçmişten günümüze hekimler her dönemde, toplum içinde kıymet verilen ve büyük değer atfedilen kişiler olmuşlardır. $\mathrm{Bu}$ durum onların yetenekleri/şifa verme kudreti yani tıbbi güçlerinden kaynaklanmaktadır [4]. Ayrıca hekimler, sağlık hizmetlerinin uygulayıcısı olmaları sebebiyle sağlık alanının kontrolünü ellerinde bulundurmaktadır [5]. Türkiye'de hastanelerin yönetimi 694 Sayılı KHK [6] ile tamamen hekimlere bırakılmış ve başhekimlerin mutlak suretle hekimlerden seçilmesi karara bağlanmıştır. Ayrıca ülkemizde görev yapan başhekim yardımcıları için hekim olma zorunluluğu olmasa dahi, çoğu başhekim yardımcısı da hekimlerden oluşmaktadır. $\mathrm{Bu}$ durum hekimlerin kendi asli görevlerinin yanında bir de yönetimsel konularla uğraşmalarına sebep olmaktadır. Hekimlik mesleğinin temel amacı sağlık hizmetini sunmak tıp biliminin gereklerini icra etmektir. Ancak yönetici pozisyonlarına geldiklerinde bu görevlerinin yanına idari görevler de eklenmektedir.

Eğitimleri süresince sadece tıbbi bilgiyle ve uygulamalarıyla donatılmış hekimler, yönetici olduklarında bazı sorunlar yaşayabilmektedir. Hem tıbbi hem de idari işleri yürütmekle görevli olan hekimler bünyelerinde hem aldıkları eğitim kaynaklı profesyonel kimlik hem de yaptıkları görev dolayısıyla kazandıkları iş kimliği ya da iş rolü barındırmaktadır. Bu durum melez iş kimliği olarak adlandırılmıştır. Melez iş kimliğine sahip hekimler de melez hekim yönetici olarak değerlendirilmektedir [7]. Yine Kaya [8] tarafından yapılan araştırmada uzun vadede hekim yöneticilerin, hekimlik yeteneklerinin köreleceği ve bu durumdan endişeli oldukları vurgulanmıştır.

Hekimlerin hekimlik yeteneklerinin körelmesi, ülkemiz adına bir hekimin kaybı anlamına gelmektedir. Böyle bir gerçeğin yanı sıra ülkemiz adına her bir hekimin ne denli yüksek maliyetlerle yetiştirildiği unutulmamalıdır. 2012 yılında yapılmış bir çalışmada bir hekim adayının 6 yıllık eğitiminin ortalama maliyetinin 200 bin TL civarında olduğu tespit edilmiştir [9]. Üzerinden geçen yıllar ve şu anki ekonomik koşullar göz önüne alındığında bu maliyetlerin daha da artmış olacağı unutulmamalıdır. Dolayısıyla Türkiye'de bir tane hekimin dahi körelmesinin göze alınamayacağı yadsınamaz bir gerçektir.

$\mathrm{Bu}$ değerlendirmeler 1şı̆̆ında çalışmanın amacı; şu an itibariyle Türkiye'de yer alan kamu hastanelerinde yönetici pozisyonunda çalışmakta olan hekimlerin profillerini ortaya çıkarmaktır. Bu kapsamda ne kadar hekim yöneticinin var olduğu ve bu hekim yöneticilerin uzmanlık alanları, cinsiyetleri gibi faktörler açısından dağılımlarının tespit edilmesi amaçlanmıştır.

\section{Materyal ve Metot}

\subsection{Araştırmanın Yöntemi:}

Nicel araştırma yöntemiyle kurgulanan bu çalışmanın verileri ikincil verilerden oluşmaktadır. İkincil veriler, farklı amaçlarla daha önce tespit edilmiş verilerin kullanılmasına dayanmaktadır. Kaynak ve zaman israfinın önüne geçilmesi, karşılaştırmalara olanak tanıması, periyodik araştırmalara imkân vermesi sebebiyle araştırmalarda ikincil verilerden yararlanılmaktadır. Dokümantasyonel, çok kaynaklı ve anket olmak üzere 3 temel ikincil veri türü bulunmaktadır [10]. Bu çalışmada dokümantasyonel ikincil verilerden yararlanılmış, bunlar içerisinden ise yazılı olmayan malzemeler kapsamına giren web siteleri tercih edilmiştir.

Çalışma tanımlayıcı bir araştırma olarak tasarlanmış, ayanı zamanda açıklayıcı araştırma yönteminden de faydalanılmıştır. 


\subsection{Araştırmanın Evreni ve Örneklemi:}

Çalışmanın evrenini Türkiye'deki Sağlık Bakanlığı'na bağl hastaneler oluşturmaktadır. 2019 Sağlık İstatistikleri Yıllığ 1 Haber Bülteni'ne göre Türkiye'deki Sağlık Bakanlığı'na bağlı hastane sayı 895'tir [1]. Çalışmada örneklem seçimine gidilmeden evrenin tamamına ulaşılmaya çalışılmış ve bu kapsamda 601 hastaneden veri elde edilmiştir.

\subsection{Veri Toplama Araçları:}

Veriler 1-30 Haziran 2019 tarihleri arasında il sağllk müdürlüklerinin web sitelerinden toplanmıştır. 71 ilin il sağlık müdürlüklerinin sitelerine tek tek girilerek "hastanelerimiz" sekmesinde bulunan hastaneler (genel hastane, şehir hastanesi, eğitim araştırma hastanesi, afiliye hastane, kadın doğum ve çocuk hastanesi) çalışmaya dâhil edilmiștir.

Söz konusu hastanelerin başhekim ve başhekim yardımcılarının profillerini ortaya çıkaracak bilgiler (yaş, unvan, uzmanlık alanı, cinsiyet, hastanedeki pozisyon vb.) bahsi geçen sitelerden toplanmıştır. $\mathrm{Bu}$ sitelerde gerekli verileri olmayan 10 ilin (Artvin, Burdur, Çankırı, İstanbul, Muğla, Rize, Siirt, Aksaray, Bayburt, Karabük) verileri ise Google arama motorundan o illerde bulunan hastanelerin listesi aranarak ulaşılmış, sonra da ilgili hastanelerin başhekim, başhekim yardımcısı ve başhekim vekillerinin bilgilerine hastanelerin web siteleri üzerinden ulaşılmıştır.

\subsection{Verilerin Değerlendirilmesi:}

Elde edilen veriler için Excel üzerinde bir veri seti oluşturulmuş daha sonra SPSS programına aktarılarak analizi yapılmıştır. Analizde demografik değişkenlerin frekanslarına bakılmış ve demografik değişkenlerin kendi aralarında karşılaştırmaları yapılmıştır.

\subsection{Araștırmanın Klsitlllıkları:}

Araştırma temel olarak iki kısıt bulunmaktadır;

Bunlardan ilki incelenen hastanelerin yönetim kademelerinde yer alan başhekim ve başhekim yardımcılarının öz geçmişlerinde eksik verilerin bulunması, hali hazırda yer alan verilerin de doğru olduğunun varsayılmasıdır.

Çalışmanın ikinci kısıtı ise araştırma kapsamında il sağlık müdürlüklerinin sitelerinde hastanelerimiz sekmesi altına bulunan hastaneler içerisinden; genel hastane, şehir hastanesi, eğitim araştırma hastanesi, afiliye hastane, kadın doğum ve çocuk hastanesi başlıklarında yer alan hastanelerin alınmış olması, Türkiye genelinde yer alan özel hastanelerin, üniversite hastanelerinin ve entegre hastanelerin araştırmaya dahil edilmemiş olmasıdır.

\section{Bulgular ve Tartışma}

3.1 Bulgular3.1. Katılımcıların Demografik Özellikleri: Araştırma kapsamında yer alan bireylerin, seçilmiş bazı değişkenlere göre dağılımları Tablo 1 de verilmiştir. Çalışmanın verileri Türkiye'nin 81 ilinde bulunan hastanelerden toplanmıştır. Çalışmada 1638 hekim yöneticinin profiline ulaşılmıştır. Araştırmaya dâhil edilen hekim yöneticilerin \%81,9'unun erkeklerden, geriye kalanların (\%18.1) ise kadınlardan oluştuğu
Tablo 1. Katılımcıların Demografik Özelliklerine Dair Bulgular

\begin{tabular}{|c|c|c|}
\hline Değişkenler & Frekans & Yüzde \\
\hline \multicolumn{3}{|l|}{ Cinsiyet } \\
\hline Erkek & 1342 & 81.9 \\
\hline Kadın & 296 & 18.1 \\
\hline \multicolumn{3}{|l|}{ Yaş* } \\
\hline $25-39$ & 301 & 33.9 \\
\hline $40-49$ & 351 & 39.5 \\
\hline $50+$ & 236 & 26.6 \\
\hline \multicolumn{3}{|l|}{ Görev Unvanı } \\
\hline Başhekim & 577 & 35.2 \\
\hline Başhekim Yardımcısı & 1037 & 63.3 \\
\hline Başhekim Vekili & 24 & 1.5 \\
\hline \multicolumn{3}{|l|}{ Unvan } \\
\hline Pratisyen Hekim (Dr) & 455 & 27.8 \\
\hline Uzm. Dr. & 1035 & 63.2 \\
\hline Öğr. Üyesi & 105 & 6.4 \\
\hline Diğer & 43 & 2.6 \\
\hline \multicolumn{3}{|l|}{ Hastanenin Bulunduğu Yer } \\
\hline İl & 916 & 55.9 \\
\hline İlçe & 722 & 44.1 \\
\hline \multicolumn{3}{|l|}{ Uzmanlık Alanları } \\
\hline Temel Tip Bilimleri & 34 & 2.1 \\
\hline Dâhili Tıp Bilimleri & 613 & 37.4 \\
\hline Cerrahi Tıp Bilimleri & 459 & 28.0 \\
\hline Pratisyen Hekim & 455 & 27.8 \\
\hline Diğer & 77 & 4.7 \\
\hline \multicolumn{3}{|c|}{ Bulunulan İlin Büyüklüğü Açısından } \\
\hline Büyük Şehir & 1142 & 69.7 \\
\hline Şehir & 496 & 30.3 \\
\hline \multicolumn{3}{|l|}{ Hastanenin Türü } \\
\hline Genel Hastane & 993 & 60.6 \\
\hline Şehir Hastanesi & 69 & 4.2 \\
\hline Eğitim Araştırma Hastanesi & 327 & 20.0 \\
\hline Kadın Doğum Hastanesi & 40 & 2.4 \\
\hline Afiliye Hastane & 83 & 5.1 \\
\hline Diğer Hastaneler & 126 & 7.7 \\
\hline Toplam & 1638 & 100 \\
\hline
\end{tabular}

* Bazı katılımcıların yaşına ait veriye ulaşılamamış, yaş ile ilgili analiz 888 hekim üzerinden yapılmıştır.

görülmektedir. Buna göre hekim yöneticilerin sadece 5'te 1'inin kadınlardan oluş̧uğu görülmüştür.

Katılımcıların \%33.9'u 40 yaş altındaki kişilerden, $\% 39.5$ ' $\mathrm{i}$ ise $40-50$ yaş aralığında yer almaktadır. 50 yaş ve üzerindeki katılımcilar ise \%26.6'llk k1sm1 oluşturmaktadır. 1638 katılımcının 577'sini (\%35.2) başhekimler oluştururken 1037'si (\%63.3) başhekim yardımcılarından, \%1.5'lik bir kesim ise başhekimlik görevini vekaleten yürüten hekimlerden oluşmaktadır. Mesleki unvanı açısından bakıldığında çoğunluğun $(\% 63,2)$ uzman hekimlerden oluştuğu, bunu sirasiyla pratisyen hekim (\%27.8) ve öğretim üyelerinin (\%6.4) takip ettiği görülmektedir. Çalışmadaki başhekim ve başhekim yardımcılarının \%55.9'u büyükşehirler dışında kalan illerde bulunan hastanelerde görev yaparken \%69.7'si büyükşehirlerde görev yapmaktadır. Başhekim ve başhekim yardımcılığ 1 yapan uzman hekimler 
uzmanlık alanlarına göre değerlendirildiğinde çoğunluğun dâhili tıp bilimleri alanından (\%37.4), \%28.0'inin ise cerrahi tıp bilimleri alanından uzmanlıklarını tamamladıkları görülmektedir. Yine başhekim ve başhekim yardımcılarından 455 (\%27.8) hekimin pratisyen hekim olduğu Tablo 1'den anlaşılmaktadır. Katılımcıların özellikleri görev yaptıkları hastanelerin türleri açısından ele alındığında ise yarıdan fazlasının (\%60.6) genel hastanelerde, beşte birlik bir kısmının (\%20.0) ise eğitim araştırma hastanelerinde başhekim ve başhekim yardımcılığ yaptıkları bulgusuna ulaşılmaktadır.

3.2. Katılımciların Görev Unvanlarinın Unvan, Uzmanlık alanı, Hastane Türü, Cinsiyet, İlìlçe ve Yaş Açısından Dağılımı:

Başhekim, başhekim yardımcısı ve başhekim vekillerinin görev unvanlarının unvan, uzmanlık alanı, hastane türü, cinsiyet, il/ilçe ve yaş açısından dağılımı Tablo 2'de gösterilmiştir.
Katılımcıların görev unvanlarının unvan açısından değerlendirildiği Tablo 2' ye bakıldığında başhekim (\%70.8), başhekim yardımcısı (\%58.9) ve başhekim vekili (\%66.7) pozisyonlarında oransal olarak en fazla uzman doktorların olduğu görülmektedir. Başhekimlerin 15.7'si pratisyen hekim ve \%13.5'i öğretim üyesinden oluşmaktadır. Başhekim yardımcılarının ise \%34.3'ü pratisyen hekimlerden ve \%2.6's1 öğretim üyelerinden oluşmaktadır. Başhekim vekillerinin ise $\% 33.3$ 'ü pratisyen hekimlerden oluşmaktadır.

Katılımcıların unvan açısından dağılımları genel olarak ele alındığında başhekim, başhekim yardımcılığ 1 ve başhekim vekilliği pozisyonlarının tamamında bulunan kişilerin büyük çoğunluğunun uzman hekimlerden oluştuğu görülmektedir. $\mathrm{Bu}$ oran başhekimlikte \%70'lere kadar çıkarken başhekim yardımcılığında $\% 58$ 'lere düşmektedir.

Tablo 2. Katılımcıların Görev Unvanlarının Unvan, Uzmanlık Alanı, Hastane Türü, Cinsiyet, İ/İlçe ve Yaş Açısından Dağılımına Dair Bulgular

\begin{tabular}{|c|c|c|c|c|c|c|}
\hline \multirow[b]{2}{*}{ Değişkenler } & \multicolumn{6}{|c|}{ Görev Unvanı } \\
\hline & $\begin{array}{l}\text { Başhekim } \\
\text { Frekans }\end{array}$ & $\begin{array}{c}\text { Başhekim } \\
\text { Yüzde }\end{array}$ & $\begin{array}{c}\text { Başhekim } \\
\text { Yardımcısı } \\
\text { Frekans }\end{array}$ & $\begin{array}{c}\text { Başhekim } \\
\text { Yardımcısı } \\
\text { Yüzde }\end{array}$ & $\begin{array}{c}\text { Başhekim } \\
\text { Vekili } \\
\text { Frekans } \\
\end{array}$ & $\begin{array}{c}\text { Başhekim } \\
\text { Vekili } \\
\text { Yüzde }\end{array}$ \\
\hline \multicolumn{7}{|l|}{ Unvan } \\
\hline Pratisyen Hekim (Dr) & 91 & 15.7 & 356 & 34.3 & 8 & 33.3 \\
\hline Uzm. Dr. & 408 & 70.8 & 611 & 58.9 & 16 & 66.7 \\
\hline Öğr. Üyesi & 78 & 13.5 & 27 & 2.6 & 0 & 0 \\
\hline Diğger & 0 & 0 & 43 & 4.2 & 0 & 0 \\
\hline \multicolumn{7}{|l|}{ Uzmanlık Alanı } \\
\hline Temel Tıp Bilimleri & 8 & 1.39 & 25 & 2.42 & 1 & 4.16 \\
\hline Dâhili Tıp Bilimleri & 259 & 44.88 & 345 & 33.26 & 9 & 37.5 \\
\hline Cerrahi Tıp Bilimleri & 210 & 36.39 & 246 & 23.73 & 3 & 12.5 \\
\hline Pratisyen Hekim & 91 & 15.78 & 356 & 34.33 & 8 & 33.34 \\
\hline Diğger & 9 & 1.56 & 65 & 6.26 & 3 & 12.5 \\
\hline \multicolumn{7}{|l|}{ Hastane Türü } \\
\hline Genel Hastane & 454 & 78.68 & 522 & 50.34 & 17 & 70.84 \\
\hline Şehir Hastanesi & 10 & 1.74 & 59 & 5.68 & 0 & 0 \\
\hline $\begin{array}{l}\text { Eğitim Araştırma } \\
\text { Hastanesi }\end{array}$ & 55 & 9.53 & 269 & 25.94 & 3 & 12.5 \\
\hline Kadın Doğum Hastanesi & 12 & 2.08 & 27 & 2.61 & 1 & 4.16 \\
\hline Afiliye Hastane & 11 & 1.91 & 71 & 6.85 & 1 & 4.16 \\
\hline Diğer Hastaneler & 35 & 6.06 & 89 & 8.58 & 2 & 8.34 \\
\hline \multicolumn{7}{|l|}{ Cinsiyet } \\
\hline Erkek & 513 & 88.90 & 809 & 78.01 & 20 & 83.30 \\
\hline Kadın & 64 & 11.10 & 228 & 21.99 & 4 & 16.70 \\
\hline \multicolumn{7}{|l|}{ İl/İlçe } \\
\hline İl & 192 & 33.27 & 715 & 68.94 & 9 & 37.5 \\
\hline İlçe & 385 & 66.73 & 322 & 31.06 & 15 & 62.5 \\
\hline Toplam & 577 & 100 & 1037 & 100 & 24 & 100 \\
\hline \multicolumn{7}{|l|}{ Yaş } \\
\hline $25-39$ & 118 & 33.61 & 175 & 33.26 & 8 & 72.72 \\
\hline $40-49$ & 149 & 42.45 & 200 & 38.02 & 2 & 18.18 \\
\hline $50+$ & 84 & 23.94 & 151 & 28.72 & 1 & 9.10 \\
\hline Toplam & 351 & 100 & 526 & 100 & 11 & 100 \\
\hline
\end{tabular}


Başhekimlerin \%44.88'inin dâhili tıp alanında, \%36.39'unun cerrahi tıp alanında, \%1.39'unun temel tıp alanında uzman olduğu, \%15.78'inin ise pratisyen hekim olduğu görülmektedir. Başhekim yardımcılarının \%34.33'ü pratisyen hekimlerken, \%33.26's1 dâhili tıp uzmanlarından, \%23.73' ü cerrahi tıp uzmanlarından ve $\% 2.42$ 'si temel tıp alanındaki uzmanlardan oluşmaktadır. Başhekim vekillerinin \%37.5'i dâhili tıp bilimlerinde, $\% 12.5$ 'i cerrahi tıp bilimlerinde, \%4.16's1 temel tıp bilimlerinde uzmanlașmıș hekimlerden oluşurken, \%33.34'ü pratisyen hekimlerden oluşmaktadır. Tablo 2'de uzmanlık alanları açısından genel bir değerlendirme yapılırsa; temel tıp bilimleri alanında uzmanlık yapan hekimlerin başhekimlik, başhekim yardımcılığı ve başhekim vekilliği gibi pozisyonlarda çok fazla yer almadığı başhekimlerde daha çok dâhili tıp bilimler alanında uzman olan hekimlerin, başhekim yardımcılığ pozisyonunda ise daha çok pratisyen hekimlerin yer aldığ1 göze çarpmaktadır. Başhekimlerin büyük çoğunluğu (yaklaşık \%85.0), başhekim yardımcılarının yaklaşık \%55:0'i uzmanlardan oluşmaktadır.

Katılımcılar hastane türlerine göre değerlendirildiğinde; başhekimlerin (\%78.68) ve başhekim vekillerinin (\%70.88) büyük çoğunluğunun, başhekim yardımcılarının yarısının (\%50.34) genel hastanelerde çalıştığı görülmektedir. Yine başhekimlerin \%9.53'ü, başhekim yardımcılarının \%25.94'ü eğitim araştırma hastanelerinde görev yapmaktadır.

Tablo 2'den başhekimlerin \%88.9'unun erkelerden geriye kalanların ise kadınlardan müteşekkil olduğu görülmektedir. Başhekim yardımcılarında kadınların oranı başhekimlerdeki oranın yaklaşık olarak iki katına çıkarak \%21.99 olmuştur. Başhekim vekillerinin ise \%16.70'i kadınlardan geriye kalanlar erkeklerden oluşmaktadır. Tablo 2 cinsiyet açısından ele alındığında başhekim, başhekim yardımcısı ve başhekim vekili gibi idari pozisyonlarda kadın yöneticilerin oranının oldukça az olduğu bulgusuna ulaşılmaktadır. Hâlbuki T.C Sağlık Bakanlığı'nın verilerine göre Türkiye'deki hekimlerin yaklaşık olarak \%56'sı erkek, \%44'ü kadın hekimlerden oluşmaktadır [11]. Bu durum erkek ve kadın hekim sayıları neredeyse eşit olmasına rağmen yönetim kademelerinde kadın hekimlerin yeterince yer almadıklarını göstermektedir.

Yine tablo 2'den başhekimlerin üçte ikisinin ilçelerde (merkez ilçeler de dâhil), üçte birinin ise illerde olduğu, başhekim yardımcılarının ise yaklaşık olarak üçte ikisinin illerde, üçte birinin ise ilçelerde olduğu görülmektedir. İllerdeki hastanelerin büyüklüğünün ve bundan dolayı daha fazla başhekim yardımcısı atanmış olmasından dolayı böyle bir tablonun ortaya çıkmış olduğu düşünülmektedir.

Tablo 2'de başhekim ve başhekim yardımcılarının yaklaşık olarak \%40.0'nın 40-49 yaş aralığındaki hekimlerden oluştuğu, başhekim vekillerinde ise çoğunluğun 25-39 yaş aralığında olduğu görülmektedir. Başhekimlerin \%33.61'i 25-39, \%23.94'ü 50 ve üzeri yaş grubundaki; başhekim yardımcılarının \%33.26'sı 25-39, $\% 28.72$ 'si 50 ve üzeri yaş aralığındaki hekimlerden oluşmaktadır. Tüm unvanlarda (başhekim, yardımcısı ve vekili) en az oranın 50 ve üzeri yaş grubunda, en yüksek oranın ise başhekim ve yardımcılarında 40-49 yaş aralığında, başhekim vekillerinde ise 25-39 yaş aralığında olduğu yorumu çıkartılabilir.

3.3. Katılımcıların Yaşlarının Çalıştıkları Bölgelere Göre Dă̆llımı:

Katılımcıların yaşlarının çalıştıkları bölgeler açısından dağılımlarının (Tablo 3) incelendiği frekans ve yüzde tablosu aşağıda sunulmuştur. Araştırma kapsamında incelenen hekim yöneticilerin yaşlarının, çalışmakta oldukları bölgeler açısından incelenmesine ilişkin veriler Tablo 4'de yer almaktadır. Tabloya göre, Doğu Anadolu (\%57.1) ve Güney Doğu Anadolu (\%56.6) bölgelerinde çalışmakta olan hekim yöneticilerin büyük bölümünün 25-39 yaş aralığındaki nispeten genç hekimlerden oluştuğu görülecektir. Sirasıyla Karadeniz (\%48.7), Akdeniz (\%42.4), İç Anadolu (\%38.3), Ege (\%37.7), bölgelerinde ise, yaş ve tecrübe olarak nispeten yüksek sayılabilecek, 40-49 yaş aralığındaki hekimlerin yöneticilik yaptıkları görülmüştür.

Marmara bölgesi ise 50 yaş ve üzeri hekim yöneticilerin sayısı en yüksek (\%38.5) olan bölge olarak karşımıza çıkmaktadır.

Bu tabloya göre yaş olarak genç olan hekim yöneticilerin ilk görev yerlerinin çoğunlukla Doğu ve Güney Doğu Anadolu bölgeleri olduğu çıkarımı yapılabilir. Kılıç ve Tunç'un çalışmasında [12], Doğu bölgelerinde çalışmakta olan hekimlerin ailelerine yakın yerlerde çalışmak istedikleri tespit edilmiştir. $\mathrm{Bu}$ durumu destekleyecek şekilde araştırma kapsamında bu bölgelerde yer alan illerden CV'leri incelenen hekim yöneticilerin, genellikle memleketlerine yakın yerlerde görev yapan kişiler olduğu ve ayrıca yabancı uyruklu kişilerin de bu bölgelerde görev yaptığı görülmüştür.

Tablo 3. Katılımcıların Yaşlarının Bölgeler Açısından Dağılımı

\begin{tabular}{|c|c|c|c|c|c|c|c|c|c|c|c|c|c|c|}
\hline \multirow{3}{*}{$\begin{array}{c}\text { Değişken } \\
\text { Yaş }\end{array}$} & \multicolumn{14}{|c|}{ Bölgeler } \\
\hline & \multicolumn{2}{|c|}{ Akdeniz } & \multicolumn{2}{|c|}{$\begin{array}{c}\text { Doğu } \\
\text { Anadolu }\end{array}$} & \multicolumn{2}{|c|}{ Ege } & \multicolumn{2}{|c|}{$\begin{array}{c}\text { Güney } \\
\text { Doğu } \\
\text { Anadolu }\end{array}$} & \multicolumn{2}{|c|}{$\begin{array}{c}\text { İç } \\
\text { Anadolu }\end{array}$} & \multicolumn{2}{|c|}{ Marmara } & \multicolumn{2}{|c|}{ Karadeniz } \\
\hline & $\mathbf{F}$ & $\%$ & $\mathbf{F}$ & $\%$ & $\mathbf{F}$ & $\%$ & $\mathbf{F}$ & $\%$ & $\mathbf{F}$ & $\%$ & $\mathbf{F}$ & $\%$ & $\mathbf{F}$ & $\%$ \\
\hline $25-39$ & 43 & 34.4 & 40 & 57.1 & 43 & 35.2 & 30 & 56.6 & 41 & 32 & 55 & 23.5 & 46 & 30.7 \\
\hline $40-49$ & 53 & 42.4 & 23 & 32.9 & 46 & 37.7 & 16 & 30.2 & 49 & 38.3 & 89 & 38.0 & 73 & 48.7 \\
\hline $50+$ & 29 & 23.2 & 7 & 10 & 33 & 27.1 & 7 & 13.2 & 38 & 29.7 & 90 & 38.5 & 31 & 20.6 \\
\hline Toplam & 125 & 100 & 70 & 100 & 122 & 100 & 53 & 100 & 128 & 100 & 134 & 100 & 150 & 100 \\
\hline
\end{tabular}


Tablo 4. Katılımcıların görev unvanlarının yaş ve bölge açısından dağılımı

\begin{tabular}{|c|c|c|c|c|c|c|c|c|c|c|c|c|c|c|c|}
\hline \multirow{2}{*}{\multicolumn{2}{|c|}{ Değişkenler }} & \multicolumn{14}{|c|}{ Bölge } \\
\hline & & \multicolumn{2}{|c|}{ Akdeniz } & \multicolumn{2}{|c|}{$\begin{array}{c}\text { Doğu } \\
\text { Anadolu }\end{array}$} & \multicolumn{2}{|c|}{ Ege } & \multicolumn{2}{|c|}{$\begin{array}{c}\text { Güney } \\
\text { Doğu } \\
\text { Anadolu }\end{array}$} & \multicolumn{2}{|c|}{$\begin{array}{c}\text { İç } \\
\text { Anadolu }\end{array}$} & \multicolumn{2}{|c|}{ Marmara } & \multicolumn{2}{|c|}{ Karadeniz } \\
\hline $\begin{array}{c}\text { Görev } \\
\text { Unvanı }\end{array}$ & Yaş & $\mathbf{F}$ & $\%$ & $\mathbf{F}$ & $\%$ & $\mathbf{F}$ & $\%$ & $\mathbf{F}$ & $\%$ & $\mathbf{F}$ & $\%$ & $\mathbf{F}$ & $\%$ & $\mathbf{F}$ & $\%$ \\
\hline \multirow{3}{*}{ Başhekim } & 25-39 & 12 & 27.3 & 23 & 63.9 & 18 & 37.5 & 12 & 52.2 & 15 & 32.6 & 20 & 23 & 18 & 27.3 \\
\hline & $40-49$ & 22 & 50 & 11 & 30.6 & 17 & 35.4 & 9 & 39.1 & 20 & 43.5 & 38 & 43.7 & 32 & 48.5 \\
\hline & $50+$ & 10 & 22.7 & 2 & 5.5 & 13 & 27.1 & 2 & 8.7 & 11 & 23.9 & 29 & 33.3 & 16 & 24.2 \\
\hline \multirow{3}{*}{$\begin{array}{c}\text { Başhekim } \\
\text { Yard. }\end{array}$} & $25-39$ & 30 & 38 & 13 & 43.3 & 25 & 34.7 & 17 & 58.6 & 24 & 30 & 35 & 23.8 & 28 & 33.3 \\
\hline & $40-49$ & 31 & 39.2 & 12 & 40 & 27 & 37.5 & 7 & 24.1 & 29 & 36.3 & 51 & 34.7 & 41 & 48.8 \\
\hline & $50+$ & 18 & 22.8 & 5 & 16.7 & 20 & 27.8 & 5 & 17.2 & 27 & 33.8 & 61 & 41.5 & 15 & 17.9 \\
\hline \multirow{3}{*}{$\begin{array}{c}\text { Başhekim } \\
\text { Vekili }\end{array}$} & $25-39$ & 1 & 50 & 4 & 100 & 0 & 0 & 1 & 100 & 2 & 10 & 0 & 0 & 0 & 0 \\
\hline & $40-49$ & 0 & 0 & 0 & 0 & 2 & 100 & 0 & 0 & 0 & 0 & 0 & 0 & 0 & 0 \\
\hline & $50+$ & 1 & 50 & 0 & 0 & 0 & 0 & 0 & 0 & 0 & 0 & 0 & 0 & 0 & 0 \\
\hline
\end{tabular}

Tecrübe ve yaş açısından değerlendirildiğinde ise Marmara bölgesinin daha tecrübeli hekim yöneticilere sahip olduğu görülecektir.

\subsection{Katılımcıların Görev Unvanlarının Yaş Ve Bölge Açısından Dă̆glımı:}

Katılımcıların görev unvanlarının yaş ve bölge açısından dağılımlarının (Tablo 4) incelendiği frekans ve yüzde tabloları aşağıda yer almaktadır.

Katılımcıların unvan ve yaşları, çalıştıkları bölgelere göre değerlendirildiğinde; Doğu Anadolu (\%63.5), Güney Doğu Anadolu (\% 52.2) ve Ege (\%37.5) bölgelerinde çalışmakta olan başhekimlerin yaşlarının 25-39 yaş aralığında olduğu tespit edilmiştir. 40-49 yaş aralığında ise Akdeniz (\%50), Karadeniz (\%48.5), Marmara (\%43.7) ve İç Anadolu (\%43.5) bölgeleri öne çıkmaktadır. Oransal olarak 50 yaş ve üzerinde en çok başhekim barındıran bölge ise Marmara (\%33.3) bölgesidir.

Başhekim yardımcılarında ise; 25-39 yaş aralığında Güney Doğu Anadolu (\%58.6) ve Doğu Anadolu (\%43.3) bölgeleri öne çıkmaktadır. 40-49 yaş aralığındaki başhekim yardımcılarında ise, sırasıyla Karadeniz (\%48.8), Akdeniz (\%39.2), Ege (\%37.5) ve İç Anadolu (\%36.3) öne çıkmaktadır. Marmara bölgesinin ise yine 50 ve üzeri yaş aralığında (\%41.5) ilk sırada olduğu görülmektedir.

Başhekim vekillerinde; Doğu Anadolu, Güney Doğu Anadolu ve İç Anadolu Bölgelerinde görev yapanların tamamı 25-39 yaş aralığındadır. Ege bölgesinde başhekim vekillerinin tamamı 40-49 yaş aralığında iken Akdeniz bölgesinde 20-39 yaş aralığında 1 kişi, 50 yaş ve üzerinde yine 1 kişi bulunmaktadır. Marmara ve Karadeniz bölgelerinde yaş bilgisi girilmiş başhekim vekili bulunmamaktadır. Tablo değerlendirildiğinde Doğu ve Güney Doğu bölgelerinde genç başhekimler kendilerine genç başhekim yardımcıları tercih ederken Ege ve Marmara bölgelerinde genç başhekimlerin, nispeten tecrübeli başhekim yardımcıları tercih ettiği görülmektedir. Diğer bölgelerde ise başhekimler kendi akranları olan başhekim yardımcıları ile çalışmayı seçtiği çıkarımında bulunulabilir.

\subsection{Tartışma}

Bu çalışmada Türkiye' deki kamu hastanelerinde yönetici pozisyonunda görev yapan hekimlerin profilleri ele alınmıştır. İl sağlık müdürlüklerinin web sitelerine girilerek hastanelerimiz sekmesinde bulunan hastanelerdeki hekimlerin profilleri incelenmiş, bu kapsamda örneklem seçimine gidilmeyerek kamu hastanelerinde görev yapan 1638 hekim yöneticinin profili incelenmiştir. 1638 hekim yöneticinin \%63.2'sinin uzman hekim, \%27.8'inin pratisyen hekim ve \%6.4'ünün öğretim üyesi olduğu görülmektedir.

T.C. Sağlık Bakanlığı tarafından yayınlanan T.C. Sağlık Bakanlığı 2019 Sağlık İstatistikleri Yıllığı Haber Bülteni'ne [1] göre Türkiye'deki kamu hastanelerinde 97145 hekim görev yapmaktadır. Bunlardan 44698'i (\%46.01) uzman, 42300'ü (\%43.54) pratisyen, 10147'si (\%10.44) ise asistan hekimlerden oluşmaktadır. Veriler incelendiğinde; Sağlık Bakanlığının pratisyen ve uzman hekim sayılarının bir birine yakın olduğu görülmektedir. Fakat hastanelerde görev yapan mevcut yöneticiler ele alındığından büyük çoğunluğun (\%63.2) uzman hekimlerden oluştuğu görülmektedir. Öğretim üyesi hekimler de uzman hekim kategorisinde ele alındığında hekim yöneticilerin yaklaş1k \%70'inin uzman hekimlerden oluştuğu görülmektedir. Hâlbuki hekimlerin özellikle de uzman hekimlerin yöneticilik görevlerinden dolayı, yöneticilikle bütünleşerek, asıl meslekleri olan hekimlikten uzaklaştıkları ve bu sebeple mesleklerinde körelebilecekleri konusu çeşitli çalışmalarda eleştirilmektedir $[8,13,14,15,16]$

Çalışmada önemli bulgulardan birisi de hekim yöneticilerin büyük çoğunluğunun (\%81.9) erkek hekimlerden oluşmasıdır.

T.C. Sağlık Bakanlığı 2019 Yılı Faaliyet Raporu [11] incelendiğinde Sağlık Bakanlığı bünyesinde fiili çalışan personelin kadın-erkek sayısının neredeyse eşit olduğu görülmektedir. Personel sayısında kadın-erkek ayrımı açısından afaki bir fark görülmezken hekim yöneticilerde bu farkın uçurum derecesinde açıldığı görülmektedir. Bu farkın açılmasındaki en büyük engelin cam tavan sendromu olabileceği düşünülmektedir. Çeşitli çalışmalarda $[17,18,19,20]$ cam tavan sendromunun 
kadınları üst düzey pozisyonlara gelmede engellediği ifade edilmektedir.

$\mathrm{Bu}$ çalışmada da başhekimlik görevinde çalışan kadın hekimlerin oranı \%11.1 iken baş hekim yardımcılığında bu oran \%21.9'a çıkmıştır. En üst pozisyonun bir altı olan başhekim yardımcılığında kadın yöneticilerin oranı başhekimliğe göre iki kat artmıştır. Yine Aycan'ın çalışmasından aktaran Örücü ve diğerlerinin [21] kadının iş hayatında üst pozisyonlara gelmesinin kadın yöneticilerin, erkek yöneticilerin ve kişilerin kendilerinin koyduğu bariyerlerle engellendiğini ifade etmektedir. Ev işlerini kadının yapması gerektiği ve erkeğin kadından emir alamayacağ gibi toplumsal kalıp yargılar, kadının doğum yaptığında izne ayrılması ile görevin aksayacağ gibi çeşitli gerekçelerle kadının üst pozisyonlara gelmesinin engellendiği söylenilebilir.

Çalışmada başhekimlerin \%42.45'i, başhekim yardımcılarının ise \%38.02'si 40-49 yaş aralığındaki hekimlerden; yine başhekimlerin $(\% 66.39)$ ve başhekim yardımcılarının (\%66.74) yaklaşık üçte ikilik kısmı 40 yaş ve üzeri bireylerden oluşmaktadır. Sağlık hizmetlerinin sunumunda hatanın telafisi yok denecek kadar azdır. İnsan sağlığı ve yaşamıyla ilgili bir alan olması nedeniyle en küçük hata bireylerin hayatına mal olabileceği [22] için diğer alanlara nazaran, sağlik hizmetlerinin yönetilmesinde tecrübenin/deneyimin önemi daha fazladır. Bu sebeple orta yaş ve üzeri bireylerin yöneticilik görevlerinde daha fazla oldukları söylenebilir.

Çalışmada Doğu Anadolu ve Güneydoğu Anadolu Bölgelerindeki yöneticiler çoğunlukla genç (25-39 yaş) hekimlerden oluşurken, Marmara Bölgesinde 50 yaş ve üzeri hekimlerden oluştuğu görülmektedir. Doğu ve Güneydoğu bölgelerindeki bu durumun gerekçeleri arasında hekimlerin ilk atamalarında öncelikle Doğu ve Güney Doğu Bölgelerinde yer alan illere (5. ve 6. Bölge) atanmaları [23] gösterilebilir.

Ülkemizin belirli bölgelerinin, Özellikle de Doğu ve Güneydoğu Anadolu Bölgelerindeki, iklim ve tabiat şartlarının kötülüğü coğrafi açıdan bölgesel eşitsizliklere sebep olabilmektedir [24]. Olumsuz coğrafi şartlar, şehrin ekonomik yapısının kötü olması, mesleki gelișim imkânının az olması gibi nedenler bir bölgeden başka bir bölgeye gidiş için itici faktörler; iyi coğrafi şartlar ve ilin gelişmişlik düzeyi gibi durumlar çekici faktörler olabilmektedir [25] Buradan hareketle genel ve sağllk alanındaki gelişmişlik düzeyi diğer bölgelere göre düşük olan Doğu ve Güneydoğu Anadolu [26] Bölgelerine atanan hekimlerin zorunlu hizmetini doldurduktan sonra batı illerine geçiş yapma kararı aldıkları düşünülmektedir. Çünkü TÜİK verileri incelendiğinde genel olarak da göç hızının en fazla olduğu bölgeler Doğu ve Güneydoğu Anadolu Bölgeleri iken en az olduğu bölgenin Marmara Bölgesi olduğu görülmektedir [27]. Zorunlu hizmetlerini bitiren hekimlerin yeni görevlerine geçmesiyle bu bölgelere yeniden genç hekimlerin gelmesi sonucu Doğu Anadolu ve Güneydoğu Anadolu Bölgelerinde genç hekimlerin çoğunlukta olmasını beraberinde getirmiş olabilir.
Alkan ve Erdem'in yapmış oldukları çalışmaya göre evlilik durumu ve çocukların daha iyi okullarda eğitim görme imkânı bir bölgeyi çekici hale getirmektedir [25] Gelişmişlik düzeyi açısından Marmara Bölgesinin yüksek gelişmişlik düzeyine sahip olması [26] buradaki hekim yöneticilerin diğer bölgelere göre yaşça büyük olmasında etkili olmuştur denilebilir. Yine evlilik durumu açısından bakıldığında Taycan ve diğerlerinin Doğu Anadolu Bölgesinde görev yapan devlet hizmet yükümlülüğü (zorunlu hizmet) bulunan (100 hekim) ve bulunmayan (39 hekim) hekimler ile yapmış oldukları çalışmada devlet hizmet yükümlülüğü bulunan hekimlerin yaş ortalamasının 29 olduğu, 59 hekimin bekâr olduğu ve evli olan 41 hekimin neredeyse yarısının (17 hekim) eşiyle birlikte ikamet etmediği bulunmuştur [28]. Buradan hareketle zorunlu görevini yapmak için Doğu Anadolu ve Güneydoğu Anadolu Bölgeleri'ne gelen hekimlerin zorunlu sebeplerden veya zaten bitirince dönerim düşüncesinden dolayı ailelerini yanlarında getirmedikleri ve görev süresi dolunca Batı bölgelerine doğru geçiş yapmaya çalıştıkları söylenebilir. O yüzden de bu bölgedeki yönetici hekimlerin genç hekimlerden oluştuğu söylenilebilir.

Doğu illerinde genç yönetici hekimlerle daha sık karşılaşılmasının bir diğer sebebi de bu illerde zorunlu hizmet süresi daha kısa olması [23] ve bu süreyi tamamladıktan sonra bölgeden ayrılma düşüncesinde olan genç hekimlerin verilen yöneticilik unvanı neticesinde bölgede daha fazla kalabileceği düşüncesi olarak düşünülebilir. Bu durumu destekler şekilde Kılıç ve Tunç tarafından yapılan araştırmada [12], bölgede çalışmakta olan hekimleri bu illerde tutan en önemli sebepler arasında prestij ve yüksek gelir beklentisi olduğu ifade edilmektedir.

Yapılan çalışmada görev unvanları ve bölge kriterleri açısından hekimlerin yaş grupları ele alındığında Doğu Anadolu ve Güneydoğu Anadolu bölgelerindeki başhekimlerin \%50'den fazlasının 25-39 yaş aralığında olduğu görülmektedir. Başhekim yardımcılarında ise bu oran \%50'nin altında olsa da yine en yüksek oran 25-39 yaş aralığındadır. Burada genç başhekimlerin yardımcılarını da genç hekimlerden tercih ettiği yorumu yapılabilir.

Çalışmada tüm başhekimlerin \%15.78'i, başhekim yardımcılarının ise \%34.33'ü pratisyen hekimlerden oluşmaktadır. Başhekim yardımcılarına gelince pratisyen hekimlerin oranı artmaktadır. Araştırmada başhekim (\%70.8) ve başhekim yardımcılarının (\%58.9) yarıdan fazlasının uzman hekimlerden; uzmanlık alanları açısından ise başhekimlerin \%43.9'luk, başhekim yardımcılarının ise \%39.9'luk bir kesiminin cerrahi tıp alanında uzman olduğu görülmektedir. Bunun sebebi cerrahi hekimlerin hem hekimler arasında hem de halk arasında en üst düzeyde görülmeleri [24] nedeniyle yöneticilik mesleğini de en iyi onların yapacağına inanılmasıdır. Fakat farklı bir gözle bakıldığında, diğer tıp alanlarına nazaran cerrahi tıp alanı daha fazla el becerisi gerektiren bir alandır. O yüzden cerrahi hekimler ameliyatlarla sürekli olarak kendilerini zinde tutmalıdır. Yoksa cerrahlar bir süre sonra mesleki körelme 
yaşayabilirler. Kaya'nın [8] yapmış olduğu nitel araştırmada bazı hekim yöneticilerin bu durumu;

"Normalde ben çok hasta bakarım. Günde 18-20 hasta bakabilirken şimdi en fazla iki hasta bakabiliyorum sadece. $\mathrm{O}$ yüzden mesleğimi biraz ihmal ettim aslında. Yani hekimim diyorum ya size burası beni hekimlikten alıkoyuyor. Biraz mesleğimden uzaklaşıyorum" (Mete Bey, Prof. Dr., Başhekim.),

"Bir ortopedistin 10 yıl başhekim olması sıkıntılı bir durum bence. Bir kere seminerlere düzenli gidemeyecek. Sempozyumlara gidemeyecek yani eğitimler derken, mesela ameliyatlarla ilgili yeni bir yöntem bulundu başhekimsin gidemiyorsun.” (Murat Bey, Uzm. Dr., Eski Başhekim),

"Sanırım uzun süre yöneticilik yapmaya devam edersem muhtemelen bu durum hekimliğimi köreltecektir. Evet, körelteceğini düşünüyorum. Mesela cerrahları düşünürsek bir diğer başhekim yardımcımız Yaşar Bey var yıllardır ameliyat yapmamış mesela elbette köreltecektir yani." (Beren Hanım, Uzm. Dr., Başhekim Yrd.)

Şeklinde ifade etmeleri çeşitli nedenlerle uzman hekimlerin mesleki becerilerinin köreleceğini göstermektedir.

Türkiye hekim sayısı açısından bin kişi başına düşen 1.9 hekim sayısıyla OECD ülkeleri içerisinde son sırada yer almaktadır [3]. OECD ülkeleri içerisinde nüfus olarak Türkiye'ye en yakın ülke olan Almanya'da bu oran bin kişi başına 4.3'tür. Ayrıca bu oran Amerika Birleşik Devletleri'nde 2.6, Birleşik Kırallık'ta ise 3.0 olarak tespit edilmiștir.

Uzman hekim sayıları açısından kıyaslama yapılacak olursa, Avrupa Birliği 2018 y1lı istatistiklerine göre [30]; Türkiye'de her 100 bin kişi başına 54.5 uzman hekim düşmektedir. Bu sonuçla Türkiye AB ülkeleri ile kıyasla oldukça geri kalmaktadır. Bu kapsamda her 100 bin kişi başına; Almanya'da 139, Hollanda'da 92.2, Yunanistan'da ise 267.6 uzman hekim düşmektedir.

\section{Sonuc}

Başhekim ve başhekim yardımcılarının profillerinin çıkartılması amacıyla yapılan bu çalışmada; Türkiye'deki başhekim ve başhekim yardımcılarının büyük çoğunluğunun erkeklerden, unvan açısından ise uzman hekimlerden oluştuğu sonucuna ulaşılmıştır. Uzmanlık alanları açısından ele alındığında ise çoğunluğun dâhili tıp alanında ve sonrasında cerrahi tıp alanında uzman oldukları sonucuna ulaşılmıştır.

Dolayısıyla hâlihazırda hekim açı̆̆ı fazla olan ülkemizde bir de başhekim ve başhekim yardımcılığı pozisyonuna uzman hekimlerin getirilmesi bu açı̆̆ daha da artıracaktır. Yine idari pozisyonda uzun süre kalan cerrahi hekimlerin el becerilerinin azalması ihtimali, diğer alanlarda uzmanlığını tamamlamış hekimlerin ise bilgilerinin körelme ihtimali de ayrı bir sorunu beraberinde getirecektir.

Maddi/manevi çok fazla maliyet ve zaman kaybı ile yetişen uzman hekimlerin mesleklerine yabancılaşacakları idari konumlara getirilmesi yerine, en tepede denetleyicilerin yine hekim olması kaydıyla daha alt pozisyonlara (başhekim yardımcısı gibi) alana yatkın meslek gruplarından (sağlık yönetimi, işletme, hemşirelik vb. mezunu) kişilerin getirilmesi yukarda bahsi geçen problemlerden doğacak olumsuz sonuçların bir nebze de olsa azaltılmasını sağlayacaktır. Hem de bu sayede bahsi geçen alanlarda istihdam oluşacaktır. Bundan sonra yapılacak bir çalışma ile bu çalışmada yer almayan hastane (entegre hastaneler, tıp fakülteleri vb.) türlerinin de dahil edilerek kapsamlı bir profil çıkarılmasının literatüre ve sahanın uygulayıcılarına (sağlık bakanlığı vb.) katkı sağlayacağı düşünülmektedir.

\section{Teşekkürler ve Bilgilendirme}

Bu çalışma; 10-13 Ekim 2019 tarihlerinde gerçekleşen, 3. Uluslararası 13. Ulusal Sağlık ve Hastane İdaresi Kongresi kapsamında sunulan bildirinin genişletilmiş halidir.

\section{Referanslar}

1.Sağlık İstatistikleri Yıllığı 2019 Haber Bülteni, Erișim Tarihi: 03.12.2020, https://dosyamerkez.saglik.gov.tr/Eklenti/39024,haberbulteni-2019pdf.pdf?0

2. Adrese Dayalı Nüfus Kayıt Sistemi Sonuçları, Erişim tarihi: 19. 08. 2020. http://www.tuik.gov.tr/Start.do.

3. OECD (2020), Doctors (indicator), doi: 10.1787/4355e1ec-en (Accessed on 04 December 2020)

4. Turner, B.S, Tıbbi Güç ve Toplumsal Bilgi, Çev. Ü. Tatlıcan, Bursa: Sentez yayıncilik. 2011.

5. Akdaş, A, Sur, H, Şişman, N, Gemlik, N, “İdari Görevi Bulunan Hekimlerin Sağlık Yönetimine Bakış Açıları.” SD Sağlık Düşüncesi ve Tıp Kültürü Dergisi, 2008, Sayı 5.

6. Olağanüstü Hal Kapsamında Bazı Düzenlemeler Yapılması Hakkında Kanun Hükmünde Kararname, (2017). KHK/694, 15 Ağustos 2017.

7.Kaya, R.R, Kaya, E, "Hekimlerin Yönetim Macerası: Melez İş Kimliği ve Hekim Yöneticiler.” SDÜ Sağlık Yönetimi Dergisi, 2019, 1(2), 82-102.

8. Kaya, R.R, Melez İs Kimliği: Hekim Yöneticiler Üzerine Nitel Bir Çalışma. Süleyman Demirel Üniversitesi, Sosyal Bilimler Enstitüsü. Yüksek Lisans Tezi. Isparta, 2018.

9. Abuhanoğlu, H, Cankul, İ.H, Ayanoğlu, Y, Mezuniyet Öncesi T1p Eğitimi Maliyetlerinin Belirlenmesi: Tıp Fakültesinde Bir Uygulama, Sağllkta Performans ve Kalite Dergisi, 2012, 4(2), 39-65.

10. Altunışık, R, Coşkun, R., Bayraktaroğlu, S, Yıldırım, E. Sosyal Bilimlerde Araştırma Yöntemleri, Sakarya: Sakarya Yayıncılık, 2012.

11. T.C. Sağlık Bakanlığı 2019 Faaliyet Raporu, Erişim Tarihi: 19.08.2020, https://dosyamerkez.saglik.gov.tr/Eklenti/36626,tcsaglik-bakanligi-faaliyet-raporu-2019pdf.pdf?0.

12. Kılıç, M, Tunç, S, İnsan Kaynakları Planlaması Açısından Doğu ve Güneydoğu Anadolu Bölgelerinde Çalışan Hekimlerin Sorunları ve Memnuniyet Durumlarının Değerlendirilmesi, Hacettepe Sağllk Ídaresi Dergisi, 2004, 7(1), 39-64.

13. Cascon-Pereira, R, Chillas, S, Hallier, J, Role-Meanings As A Critical Factor in Understanding Doctor Manager's Identity Work and Different Role Identities, Social Science \& Medicine, 2016, 170, 18-25.

14. Kippist, L, Fitzgerald, A, The paradoxical role of the hybrid clinician manager, Mind the Gap: Policy and Practice in the Reform of Healthcare: Proceedings of the Biennial International Conference in Organisational Behaviour in Health Care (OBHC), 2010, 11-14 Apr. 2010. Birmingham, United.

15. Joffe, M, MacKenzie-Davey, K, The Problem of Identity in Hybrid Managers: Who Are Medical Directors? International Journal of Leadership in Public Services, 2012, 8(3), 161 - 174.

16. Hayran, O. (2016), Sağlık Hizmetlerinin Yönetimi: Hekimler Mi, Profesyonel Yöneticiler Mi?, Erişim tarihi: 09. 08. 2020.

17. Soysal, A, Baysal, T, Sağlık Kurumlarında Cam Tavan Sendromu Kayseri Özel Sağlık Kurumlarında Bir Araştırma, KSÜ Sosyal Bilimler Enstitüsü Dergisi, 2016, 13(2), 225-264. 
18. Yıldız, S, Türkiye'de Cam Tavan Sendromunun Varlığ Üzerine Bir Araştırma. Organizasyon ve Yönetim Bilimleri Dergisi, 2014, 6(1), 72-90.

19. Mizrahi, R, Aracı, H, Kadın Yöneticiler ve Cam Tavan Sendromu Üzerine Bir Araştırma, Organizasyon ve Yönetim Bilimleri Dergisi, 2010, 2(1), 149-156.

20. Öğüt, A, Türkiye'de Kadın Girişimciliğin ve Yöneticiliğin Önündeki Güçlükler: Cam Tavan Sendromu, Girişimcilik ve Kalkınma Dergisi, 2006, 1(1), 56-78.

21. Örücü, E, Kılıç, R, Kılıç, T., Cam Tavan Sendromu Ve Kadınların Üst Düzey Yönetici Pozisyonuna Yükselmelerindeki Engeller: Balıkesir İli Örneği, Yönetim ve Ekonomi Dergisi, 2007, 14(2), 117 135.

22. Tengilimoğlu, D, Işık, O, ve Akbolat, M, Sağlık işletmeleri yönetimi, 9. Bask1, Ankara: Nobel Yayıncılık, 2018.

23. Sağlık Hizmetleri Temel Kanunu, Sağlık Personelinin Tazminat ve Çalışma Esaslarına Dair Kanun, Devlet Memurları Kanunu ve Tababet ve Şuabatı San'atlarının Tarzı İcrasına Dair Kanun ile Sağlık Bakanlığının Teşkilat ve Görevleri Hakkında Kanun Hükmünde Kararnamede Değişiklik Yapılmasına Dair Kanun, (Kabul Tarihi: 21.06.2005, Kanun No: 5371). Erșim Tarihi: 04.12.2020, https://www.resmigazete.gov.tr/eskiler/2005/07/20050705-2.htm.

24. Y1lmaz, Ö, Bölgesel eşitsizlik: Türkiye örneği, Atatürk Üniversitesi Íktisadi ve İdari Bilimler Dergisi, 2001, 15(1), 1-19.

25. Alkan, F, Erdem, R, Türkiye'de yurt içi sağlık personeli hareketliliğinin değerlendirilmesine yönelik bir çalışma, Hacettepe Sağlık İdaresi Dergisi, 2019, 22(3), 515-542.

26. Acar, S, Kazancık Bilen, L, Meydan, M.C, Işık, M, İllerin Ve Bölgelerin Sosyo-Ekonomik Gelişmişlik Sıralaması Araştırması SEGE-2017 Ankara.: Kalkınma Ajansları Genel Müdürlüğü, 2019.

27. TÜIK, İllerin Aldığı Göç, Verdiği Göç, Net Göç ve Net Göç Hızı, Erişim Tarihi: 04.12.2020, https://data.tuik.gov.tr/Kategori/GetKategori?p=nufus-vedemografi-109\&dil=1

28. Taycan, O, Erdoğan Taycan, S, ÇELIK, Ç, Doğu Anadolu Bölgesi'nde yer alan bir ilde devlet hizmet yükümlülüğü'nün hekimler üzerindeki etkileri ve tükenmişlik, Türk Psikiyatri Dergisi, 2013, 24(3): 190

29. Uysal, Ş.A, Sağlık Meslek Gruplarının Hubris Sendromu Eğilimlerine Dair Nitel Bir Çalışma, Doktora Tezi, Isparta: Süleyman Demirel Üniversitesi Sosyal Bilimler Enstitüsü, 2018.

30. EUROSTAT, (2020) Healthcare personnel statistics - physicians, Erişim Tarihi: 01.12.2020. https://ec.europa.eu/eurostat/statistics explained/pdfscache/37382.pdf.

http://edergi.cbu.edu.tr/ojs/index.php/cbusbed isimli yazarın CBU-SBED başlıklı eseri bu Creative Commons Alıntı-Gayriticari4.0 Uluslararası Lisansı ile lisanslanmıştır.

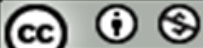

